\title{
Interaction of the Bioherbicide Myrothecium verrucaria and Glyphosate for Kudzu Control
}

\author{
Clyde Douglas Boyette ${ }^{1}$, Robert E. Hoagland2 ${ }^{2}$, Mark A. Weaver ${ }^{1}$, Kenneth C. Stetina1 \\ ${ }^{1}$ United States Department of Agriculture-Agricultural Research Service (USDA-ARS), Biological Control of Pests \\ Research Unit, Stoneville, MS, USA \\ ${ }^{2}$ United States Department of Agriculture-Agricultural Research Service (USDA-ARS), Crop Production Systems \\ Research Unit, Stoneville, MS, USA \\ Email: "doug.boyette@ars.usda.gov
}

Received 22 September 2014; revised 25 November 2014; accepted 17 December 2014

Copyright $@ 2014$ by authors and Scientific Research Publishing Inc.

This work is licensed under the Creative Commons Attribution International License (CC BY).

http://creativecommons.org/licenses/by/4.0/

(c) (i) Open Access

\section{Abstract}

Kudzu is an exotic invasive weed in the southeastern U.S. that is difficult to control with current commercial herbicides. Some success for its control has been achieved using a bioherbicidal agent, Myrothecium verrucaria (MV). Spore and mycelial formulations of MV were tested alone and in combination with glyphosate for control of kudzu (Pueraria lobata) under greenhouse and field conditions in naturally-infested areas. In greenhouse and field experiments, kudzu control increased as the concentration of spores or mycelia increased. Glyphosate alone provided $10 \%, 35 \%$, $50 \%$ and $60 \%$ control in field experiments at $0.25,0.50,0.75$ and $1.0 \mathrm{X}$ rates, respectively and MV alone spores provided $15 \%, 50 \%, 65 \%$ and $85 \%$ control at $0.25,0.50,0.75$ and $1.0 \mathrm{X}$ rates, respectively. However, when MV spores were combined with glyphosate, significantly higher control occurred than that caused by either component alone. Similar levels of control were observed for MV mycelial formulations applied alone or with glyphosate at equivalent concentrations of the fungus. The rate of disease progression was more rapid and severe at all fungal spore or mycelial formulations and herbicide rates when these propagules were applied in combination with glyphosate. In field tests, $24 \mathrm{~h}$ after application, only $20 \%$ of kudzu plants were severely damaged by MV alone $(0.25 X)$, whereas $80 \%$ were severely diseased when MV spores and glyphosate were mixed and applied at $0.25 \mathrm{X}$ rates each. A similar trend occurred with the MV mycelial formulation applied at these rates. Synergist interactions on kudzu control were observed, especially when lower levels of MV (spores or mycelia) and glyphosate were combined and applied to kudzu in the greenhouse or in the field. These results suggest that it may be possible to incorporate glyphosate to improve the bioherbicidal control potential and reduce herbicide and inoculum requirements of $M$. verrucaria spores or mycelium for controlling kudzu.

*Corresponding author.

How to cite this paper: Boyette, C.D., Hoagland, R.E., Weaver, M.A. and Stetina, K.C. (2014) Interaction of the Bioherbicide Myrothecium verrucaria and Glyphosate for Kudzu Control. American Journal of Plant Sciences, 5, 3943-3956. 


\section{Keywords}

\section{Bioherbicide, Glyphosate, Kudzu, Myrothecium verrucaria, Pueraria lobata}

\section{Introduction}

Kudzu (genus Pueraria) is a perennial vine native to Southeast Asia (China, Japan, and Korea) [1] [2] with large ovate, two to three-lobed trifoliolate leaves [3]-[6] and starchy tuberous roots (up to $40 \%-50 \%$ of plant biomass) with high water content [1] [7]-[10]. Seventeen species of Pueraria have been identified (China, Japan, India and Micronesia) and five species (P. montana, P. lobata, P. edulis, P. phaseoloides and P. thomsoni) are closely related [11] [12]. Allozyme studies and RAPD analyses indicate that U.S. kudzu populations possess a high degree of heterozygosity [13] [14] and are comprised of multiple species, with P. lobata being most predominant [14] [15]. This genetic diversity correlates with multiple introductions of kudzu into the U.S. [13] [14].

Kudzu was introduced to the U.S. in 1876 at the Centennial Exposition in Philadelphia, PA and later (1883) at the New Orleans, LA Exposition [4] [5] [16]-[18]. It was promoted as an ornamental for shading [4] [19]-[22], as cattle fodder [23], and to reduce soil erosion [24]-[29]. Kudzu seeds were widely available through mail-order catalogs and elsewhere [26] [30]-[32], the U.S. Soil Erosion Service furnished millions of kudzu seedlings for erosion control and land revitalization, and the federal government paid land owners to plant kudzu [31]. By the early 1950s, it had spread throughout the southeastern U.S., and in 1970 kudzu was listed as a common weed in the southern U.S. by the U.S. Department of Agriculture [33]. Kudzu is one of the most harmful, non-indigenous plants in the U.S., estimated to infest $>3$ million ha in the U.S., with the greatest infestations in Alabama, Georgia, and Mississippi [4] [6] [22] [34]. Its introduction and aggressiveness has produced devastating environmental consequences [22] and this unwieldy weed is spreading at a rate of 50,000 ha per year [6].

Kudzu plant stems possess nodes, from which other stems, tendrils or roots can grow [1] [4]. The rooting characteristic of nodes results in the production of vast numbers of ramets (individual vegetatively propagated clones) [33] whose numbers can range up to tens of thousands per hectare [6] [28]. Vegetative reproduction is the primary procreative strategy [35] [36] leading to rapid clonal distribution, thus confounding control efforts with herbicides or via mechanical methods [37]-[39].

A range of estimates for the economic impact of kudzu on agriculture, timber, parks, and on native plant communities and ecosystems have been published [40]-[44]. Kudzu's impact in the U.S. has been estimated at $\$ 100$ - 500 million per year in lost forest productivity [4], $\$ 5000$ per hectare each year to control kudzu, and $\sim \$ 1.5$ million per year to repair damage to power lines [4]. Kudzu management is a major problem in some national parks in the southeastern U.S. [22].

Efforts to control the spread, or remove this serious weed at specific sites are costly and labor intensive. In addition to its extensive spread, aggressiveness and the difficulty and costliness of its control, kudzu is also a host of an invasive insect, the kudzu bug (Megacopta cribraria, native to India and China. This insect, which is also predatory on soybean, was introduced into Georgia in 2009 and has spread to 6 other southern states [45] [46]. Furthermore, kudzu is a host of Asian soybean rust (Phakopsora pachyrhizi) [47] which has potential to cause billions of dollars in lost yields and increased production costs to U.S soybean producers [48]. Additionally kudzu causes losses in biodiversity and reduces aesthetic appeal in areas such as national parks, forests, and scenic highways. Kudzu also generates isoprene (photo-reactive hydrocarbon) and causes nitric oxide emission from infested soils that negatively impact air quality and atmospheric chemistry via tropospheric ozone production [2] [49] [50]. Contrary to these unintended consequences and problems brought about by the release of kudzu in the U.S., the roots and flowers have medicinal properties and the comestible leaves and stems have some culinary value [51].

Several methods (mechanical, chemical, and biological) for controlling kudzu can be used. Mechanical methods (mowing, cutting, and crown removal) are very labor and time consuming [5] [52]. Some herbicides are effective [1] but chemical treatments are expensive, and total control requires application of large amounts of herbicides [5]. Herbicides are most effective when applied consecutively, even up to ten years [4] [53] [54]. However some herbicides cannot be applied near streams, ditches, and wetlands [18]. Burning and grazing may provide effective control, but may not be feasible in urban areas, rights-of-way, etc. [33] [55]. 
An alternative method for weed control is biological control, more specifically, the bioherbicidal approach, in which plant pathogens are inundatively applied to susceptible weed populations, in a manner similar to that of chemical herbicides [56]. Various plant pathogens have been evaluated as alternatives to synthetic herbicides for controlling several different weeds [57]-[62]. An example of bioherbicide research on kudzu is the use of Pseudomonas syringae pv. phaseolicola, a bacterial pathogen that causes halo blight on this weed [63]. When augmentatively applied, $P$. syringae pv. phaseolicola caused mortality of young plants. However, because older plants readily recovered, secondary infection was lacking, and this pathogen also infected soybeans, this organism was considered ineffective and unsuitable for kudzu control [63].

The fungus Myrothecium verrucaria (Alb. \& Schwein.) Ditmar:Fr. (MV isolate IMI 361690), originally isolated from sicklepod (Senna obtusifolia L.) has a broad host range [64]-[66]. Spore applications of this bioherbicide controlled kudzu [66]-[68]. One disadvantage of this bioherbicidal fungus is the presence of mycotoxins (e.g. trichothecenes) in fungal spores that are toxic to mammals [69]. Although no mycotoxins were detected on infected kudzu plants after spore application, extreme care should be exercised in handling this material [69]. Later it was shown that these mycotoxins could be substantially reduced or eliminated by using washed spore formulations [70] or mycelial formulations obtained via liquid fermentation of the organism [71].

Improved performance of some bioherbicides can be achieved when combined with certain agrochemicals, due to additive or synergistic effects that weaken weed defenses [72]-[76]. For example, sub-lethal doses of glyphosate suppressed phytoalexin biosynthesis in sicklepod, reducing resistance of the weed to fungal infection by Alternaria cassiae and facilitating disease development [77]. Also, the bioherbicidal activity of Pyricularia setariae on green foxtail (Setaria viridis L.) was synergized by the herbicides quinclorac, glufosinate and glyphosate [78]. Sub-lethal concentrations of MV and quinclorac applied to plant tissues [hemp sesbania (Sesbania exaltata) and sicklepod] or seedlings (kudzu), resulted in additive and/or synergistic effects on growth, chlorophyll accumulation, and mortality [79]. Additionally, combinations of glyphosate and the bioherbicidal fungus, Colletotrichum truncatum, resulted in additive or synergistic interactions for improved control of hemp sesbania [80]. Synergistic or additive interactions of MV and glyphosate on kudzu and some other invasive weeds have been demonstrated [81]-[83]. However, antagonistic interactions of several commercial glyphosate products and MV have been demonstrated using sicklepod as a bioassay plant [70]. One glyphosate product (Touchdown ${ }^{\circledR}$ ) showed additive effects or synergy with MV spores [84] for controlling kudzu in the greenhouse and field. The present paper presents results on the interaction of glyphosate with MV spores and MV mycelial formulations applied at various rates for control of kudzu in greenhouse and field experiments.

\section{Materials and Methods}

\subsection{Culture and Chemical Sources}

Potato dextrose agar (PDA; 4.0 g potato starch, $20.0 \mathrm{~g}$ dextrose and $15.0 \mathrm{~g} \cdot \mathrm{agar} \cdot \mathrm{L}^{-1}$ ) was purchased from Difco Laboratories, Inc. (Detroit, MI). Silwet L-77 (non-ionic surfactant) was obtained from OSi Specialties, Inc., Danbury, CT, USA. MV strain (IMI 361690) was used throughout these studies. Glyphosate was a commercial formulation (Touchdown ${ }^{\circledR}$; di-ammonium salt of glyphosate) product of Syngenta Agrochemical Co., Greensboro, NC, USA.

\subsection{Spore Production}

MV conidial preparations were produced on PDA in Petri plates. Plates were inoculated with a 2-mm section from the edge of an actively growing MV culture from a PDA plate and inoculated plates were then inverted on open-mesh wire shelves and incubated $\left(25^{\circ} \mathrm{C}, 10\right.$ days) in lighted incubators. Photoperiods $(12 \mathrm{~h})$ were provided by cool-white fluorescent lamps at an intensity of $\sim 200 \mu \mathrm{mol} \cdot \mathrm{m}^{-2} \cdot \mathrm{s}^{-1}$ photosynthetically active radiation (PAR). The conidia were rinsed from plates with sterile distilled $\mathrm{H}_{2} \mathrm{O}$, and their densities estimated using a hemacytometer, followed by adjustment with distilled $\mathrm{H}_{2} \mathrm{O}$ to obtain the desired concentrations.

\subsection{Production of MV Mycelia}

A fermenter (Model MF-214, New Brunswick Corp., Edison, NJ, USA) was inoculated with starter inoculum and fermentations were conducted at $185-200 \mathrm{rpm}$ and $28^{\circ} \mathrm{C}$ for $48 \mathrm{~h}$. The starter inoculum consisted of 500 $\mathrm{mL}$ soy flour-corn meal medium inoculated with a $10 \mathrm{~mm}$ agar plug $\left(\sim 10^{6}\right.$ spores $)$ from a petri dish of $\mathrm{MV}$ 
spores [81]. The flask was incubated on a rotary shaker (185 - $200 \mathrm{rpm}, 28^{\circ} \mathrm{C}$ for 7 days) and mycelial fungal growth proceeded without spore production. The MV fermentation product was removed from the fermenter, homogenized in 3 - 4 L aliquots with an electric blender (3 min, Waring Model CB1043, Springfield, MO, USA) and used directly, or stored at $4{ }^{\circ} \mathrm{C}$ until use. Concentrations of the mycelial formulations used in these tests were based on percent (v/v basis) of the mycelia fermentation batch. Harvested mycelia batches from the fermenter were filtered (\#40 Whatman filter paper) and oven-dried $\left(80^{\circ} \mathrm{C}, 24 \mathrm{~h}\right)$ and dry weights were recorded in order to determine mycelia biomass (referred to as dry mycelium equivalents). The dry weight (mycelia and unspent media) of a typical fermentation batch of MV mycelia was $0.05-0.06 \mathrm{~g} \cdot \mathrm{mL}^{-1}$. Efficacy tests on each fermentation batch were conducted using hemp sesbania (a highly sensitive plant [64] [71]) as a bioassay plant. For all experiments, prior to spray application to plants, the fermentation product was homogenized in $\sim 4 \mathrm{~L}$ aliquots with an electric blender (high speed, 3 min, Waring Model CB1043, Springfield, MO, USA). All efficacy tests contained 4 replications and were repeated over time.

\subsection{Kudzu Propagation for Greenhouse Tests}

Kudzu seeds (Adams-Briscoe Seed Co., Jackson, GA, USA) were placed on moistened filter paper in Petri plates, and incubated $\left(28^{\circ} \mathrm{C}, 3\right.$ days) in dark. Germinated seeds were then planted in 7.6-cm plastic pots (one seed per pot) containing a 1:1 commercial potting mix (Jiffy Products of America, Inc., Batavia, IL, USA): sandy loam soil combination, supplemented with controlled-release (13:13:13, N:P:K) fertilizer (Grace Sierra Horticultural Products, Milpitas, CA, USA). After placement of pots on greenhouse benches, the plants were sub-irrigated daily. Greenhouse temperatures ranged from $28^{\circ} \mathrm{C}$ to $32^{\circ} \mathrm{C}$ at $40 \%-60 \% \mathrm{RH}$ with a photoperiod of $\sim 14 \mathrm{~h}$, at $1600-1800 \mu \mathrm{mol} \cdot \mathrm{m}^{-2} \cdot \mathrm{s}^{-1} \mathrm{PAR}$ as measured at midday.

\subsection{Greenhouse Experiments}

Kudzu plants (three- to five-leaf growth stage) were inoculated by spraying MV spores using a hand-held compressed air sprayer (Spray-Tool, Aervoe Industries, Gardnerville, NV, USA). Conidial treatments consisted of MV spores in $0.2 \%$ Silwet at $0.0,0.25,0.50,0.75$ and $1.0 \mathrm{X}\left(1.0 \times 10^{7}\right.$ spores $\left.\cdot \mathrm{mL}^{-1}\right)$ applied alone or combined with a glyphosate product $\left(\right.$ Touchdown $\left.^{\circledR}\right)$ at rates of $0.0,0.25,0.50,0.75$ and 1.0X $\left(1.0 \mathrm{X}=1.12 \mathrm{~kg} \cdot \mathrm{ha}^{-1}\right) \mathrm{until}^{-1}$ the foliage was thoroughly wet (ca. $100 \mathrm{~L} \cdot \mathrm{ha}^{-1}$ ). Applications were administered to plants in a bio-safety cabinet (NuAire, Model No. NU-425-400, Plymouth, MN, USA). Due to the viscosity of the MV mycelia, spray applications of equivalent rates were made using a hand-held pressurized sprayer (Spray-doc, Model 101P, Gilmour Mfg., Somerset, PA, USA).

The MV mycelial product was tested at several concentrations $(0.0,0.25,0.50,0.75$ and $1.0 \mathrm{X})$ alone or combined with glyphosate (Touchdown ${ }^{\circledR}$ ) at the rates described above. The 1.0X MV mycelial concentration contained the equivalent of $50.0 \mathrm{~g}$ mycelium (dry weight basis) $\mathrm{L}^{-1}$, and dilutions were made with distilled water. In tests with both MV spores and MV mycelia, control plants were sprayed with $0.2 \%$ Silwet L-77 only. The experiments were arranged in randomized complete block designs, containing three replications (10 pots each) and were repeated in time. Kudzu plants were excised at the soil line, oven-dried $\left(48 \mathrm{~h}, 85^{\circ} \mathrm{C}\right)$, weighed, and the percentage biomass reduction (5 days after treatment) was determined. Data were averaged following Bartlett's test for homogeneity of variance [85]. The mean percentage of plant mortalities and biomass reductions calculated for each treatment were subjected to arc-sin transformation [85]. The transformed data were statistically compared using analysis of variance (ANOVA). Values are presented as means of replicated experiments. When significant differences were detected by the F-test, means were separated with Fisher's protected LSD (FLSD) test at the 0.05 level of probability. All data were analyzed using SAS (Version 9.1, SAS Institute, Inc., Cary, NC, USA).

After inoculation, the plants were placed in a dew chamber $\left(28^{\circ} \mathrm{C}, 100 \% \mathrm{RH}\right)$ for $12 \mathrm{~h}$, and then transferred to greenhouse benches under conditions described above. Kudzu seedlings were monitored at daily intervals for disease development for 120 h (5 days) after treatment. Disease progression (severity) was based on a visual rating scale (per plant basis) [86] to estimate disease kinetics. A rating scale of 0.0 to 10.0 was used, with 0 being unaffected, and 2.0, 4.0, 6.0, $8.0=20 \%, 40 \%, 60 \%$, and 80\% leaf and stem lesion coverage/injury, respectively, and 10.0 = plant mortality. Percent control was determined by using the formula:

$$
\text { Control }(\%)=\frac{\text { Number plants killed or severely injured }(\text { ratings } 8-10)}{\text { Number plants inoculated }} \times 100 \%
$$


In the disease kinetic studies, data were analyzed using FLSD and best-fit regression analysis.

\subsection{Field Experiments}

Test plots $(2 \times 2 \mathrm{~m})$ were established in natural infestations of kudzu at two locations in close proximity (Lexington and Eden, MS, USA; $\left(33^{\circ} 0^{\prime} 16.73^{\prime \prime} \mathrm{N}, 90^{\circ} 15^{\prime} 56^{\prime \prime} \mathrm{W}\right)$. Experiments with MV spores were performed at Lexington and experiments with MV mycelia were made at Eden. Kudzu plants at both locations were inoculated in mid-August, when kudzu plants were $\sim 0.90-1.0 \mathrm{~m}$ tall at treatment time. The treatments were identical to those used in the greenhouse experiments. In all field tests, the spores or mycelia were sprayed at a carrier

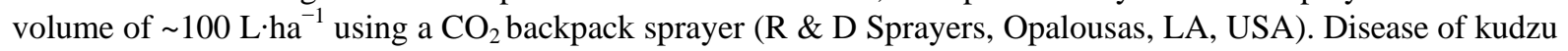
plants was monitored at daily intervals over a 5-day $(120 \mathrm{~h})$ period. Disease progression was monitored daily using a 0 to 10 rating scale, and the equation to determine weed control as described previously. Symptomatology was considered severe at ratings of 8 - 10. The experiments consisted of four replications, and were arranged in randomized complete block experimental designs. The experiments were repeated over time, and data were averaged over the 2-year testing period, after subjecting to Bartlett's test for homogeneity of variance [87]. Data were analyzed using analysis of variance. The percentage data (kudzu control) were subjected to arc-sin transformation prior to analysis and treatment means and standard errors of the mean are presented. Values are presented as means of replicated experiments. When significant differences were detected by the $F$-test, means were separated with Fisher's protected LSD test at the 0.05 probability level. In the disease kinetic studies, data were analyzed using standard mean errors and best-fit regression analysis.

\subsection{Quantification of the Interactions}

The interactions between MV and glyphosate (GLY) in mixtures were analyzed, using the Colby formula [88]: $\mathrm{E}$ (expected) $=\mathrm{X}+\mathrm{Y}-(\mathrm{XY} / 100)$, where $\mathrm{X}$ and $\mathrm{Y}$ represent percent weed control with herbicide $\mathrm{X}$ (GLY) and bioherbicide $\mathrm{Y}(\mathrm{MV})$ used alone or in combination at various rates. The observed response $\left(\mathrm{O}_{\mathrm{r}}\right)$ was experimentally determined by comparing the herbicidal activity of mixtures of $\mathrm{X}$ and $\mathrm{Y}$ containing the same rate of each component applied singly. The type of interaction was determined by comparing the $\mathrm{O}_{\mathrm{r}}$ value with $\mathrm{E}$. When $\mathrm{O}_{\mathrm{r}}=$ E, the response is considered additive, synergistic if $\mathrm{O}_{\mathrm{r}}>\mathrm{E}$, and antagonistic if $\mathrm{O}_{\mathrm{r}}$ is less than $\mathrm{E}$.

\section{Results and Discussion}

\subsection{Greenhouse Experiments}

In greenhouse tests with MV spores, kudzu control increased as the concentration of spores increased (Figure 1).

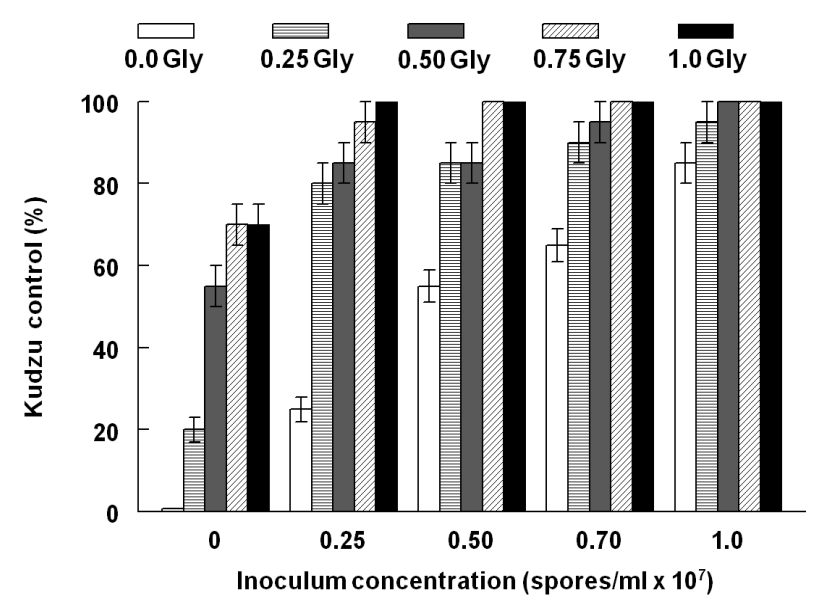

Figure 1. Effects of MV spores and glyphosate on kudzu control under greenhouse conditions, five days after treatment. Kudzu plants were in the 3- to 5-leaf growth stage at time of application. Glyphosate concentrations were 0.0 to $1.0 \mathrm{X}$ where $1.0 \mathrm{X}=1.12 \mathrm{~kg}$ ai. $\mathrm{ha}^{-1}$. Error bars represent $\mathrm{FLSD}_{0.05}$. 
Glyphosate alone provided 20\%, 55\%, 70\% and 70\% control at the $0.25,0.50,0.75$ and $1.0 \mathrm{X}$ rates, respectively, while MV spores provided 25\%, 55\%, 65\% and $85 \%$ control at $0.25,0.50,0.75$ and $1.0 \mathrm{X}$ rates, respectively. However, when MV spores were combined with glyphosate, significantly higher control values than either component alone were observed. For example, at the lowest glyphosate concentration combined with lowest spore concentration (0.25 each) 80\% control was achieved (which we deem an "acceptable level" of control), but when the glyphosate concentration increased at this low spore concentration, control increased to $85 \%$, 95\% and $100 \%$ at $0.5,0.75$ and 1.0X, respectively (Figure 1). Although some differences occurred, this trend was also generally found at higher spore concentrations when combined with glyphosate at these various concentrations. Likewise, MV mycelial formulations showed similar trends of kudzu control (Figure 2). For example, glyphosate ( $0.25 \mathrm{X})$ and MV (0.25X) each applied alone provided only $20 \%$ control of kudzu, whereas combination of glyphosate and MV mycelia at these concentrations resulted in $>80 \%$ control. Higher levels of control were demonstrated with higher levels of each component (Figure 2).

Dry weight reduction of kudzu plants caused by application of MV propagules (spores or mycelia) or glyphosate applied alone and in combination under greenhouse conditions generally paralleled the weed control data (Figure 3 and Figure 4). Combinations of MV propagules and glyphosate resulted in greater reductions in kudzu dry weights, e.g. at $0.25 \mathrm{X}$ MV spores or $0.25 \mathrm{X}$ MV mycelia plus 0.25 glyphosate caused $85 \%$ and $89 \%$ reduction in dry weight accumulation, respectively (Figure 3 and Figure 4). MV alone or glyphosate alone caused only minimal reductions in dry weight ( $<30 \%)$ (Figure 3 and Figure 4$)$.

\subsection{Field Experiments}

In field tests, glyphosate alone provided $10 \%, 35 \%, 50 \%$ and $60 \%$ kudzu control at the $0.25,0.50,0.75$ and $1.0 \mathrm{X}$, respectively, while MV spores alone provided $15 \%, 50 \%, 65 \%$ and $85 \%$ control at $0.25,0.50,0.75$ and $1.0 \mathrm{X}$, respectively (Figure 5). Thus it is evident that at the highest rates used, MV spores alone provided acceptable control, but glyphosate alone did not. When combined at the lowest rates of either component $(0.25 \mathrm{X}), 70 \%$ control of kudzu was achieved. As in the greenhouse tests, similar responses were observed with the mycelia formulations applied alone or in combination with glyphosate (Figure 6). When the two lowest rates of this herbicide and bioherbicide were applied $70 \%$ of the kudzu plants were controlled. Higher levels of glyphosate (0.75 and 1.0X) combined with the lowest MV concentration (0.25X) of either spores or mycelia were required to achieve acceptable control levels ( $\geq 80 \%$ ) (compare Figure 5 and Figure 6 ).

\subsection{Tests for Glyphosate and MV Interaction}

Both greenhouse and field test results indicated that higher levels of control occurred when glyphosate and MV

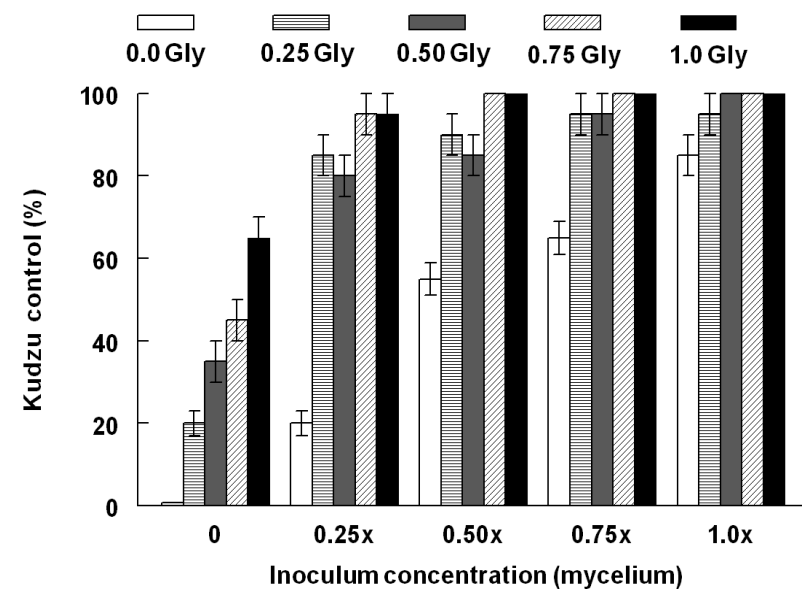

Figure 2. Effects of MV mycelia and glyphosate on kudzu control under greenhouse conditions, five days after treatment. Kudzu plants were in the 3- to 5-leaf growth stage at time of application. Glyphosate concentrations were 0.0 to $1.0 \mathrm{X}$ where $1.0 \mathrm{X}=1.12 \mathrm{~kg}$ ai. $\mathrm{ha}^{-1}$. Error bars represent $\mathrm{FLSD}_{0.05}$. 


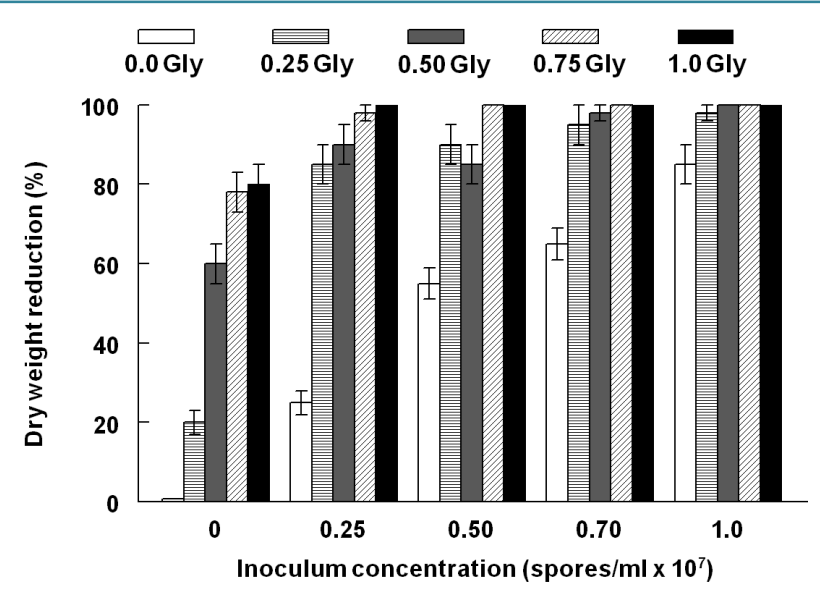

Figure 3. Kudzu dry weight reduction caused by application of MV spores alone or combined with glyphosate under green house conditions, five days after treatment. Kudzu plants were in the 3- to 5-leaf growth stage at time of application. Glyphosate concentrations were 0.0 to $1.0 \mathrm{X}$ where $1.0 \mathrm{X}=1.12 \mathrm{~kg}$ ai. $\mathrm{ha}^{-1}$. Error bars represent FLSD 0.05 .

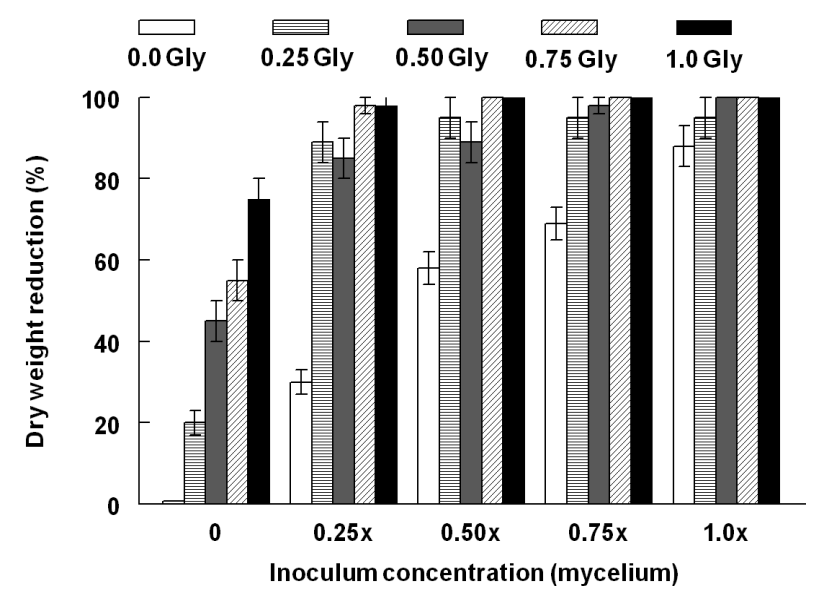

Figure 4. Kudzu dry weight reduction caused by MV mycelia alone or combined with glyphosate under greenhouse conditions, five days after treatment. Kudzu plants were in the 3- to 5-leaf growth stage at time of application. Glyphosate concentrations were 0.0 to $1.0 \mathrm{X}$ where $1.0 \mathrm{X}=1.12 \mathrm{~kg}^{\mathrm{ai}}$. ha ${ }^{-1}$. Error bars represent $\mathrm{FLSD}_{0.05}$.

propagules were combined, as compared to that of each component applied alone to kudzu plants. To elucidate the type (additive, synergistic or antagonistic) of interaction of these components, a mathematical analysis of the weed control efficacy under field conditions was performed (Table 1 and Table 2). Synergistic interactions occurred with both MV spores or mycelia at the lowest rate tested $(0.25 \mathrm{X})$ when combined with glyphosate at the four rates tested (Table 1 and Table 2). The interactions of all other combinations of MV propagules with glyphosate at various concentrations were additive. Synergistic interactions of combinations of MV spores or MV mycelia with glyphosate were also observed on kudzu control when applications were applied to plants under greenhouse conditions (data not shown).

\subsection{Disease Progression}

MV disease progression was more rapid and severe in greenhouse and field tests at all fungal spore or mycelial formulations when glyphosate was combined with either of these propagules and applied to kudzu plants when 


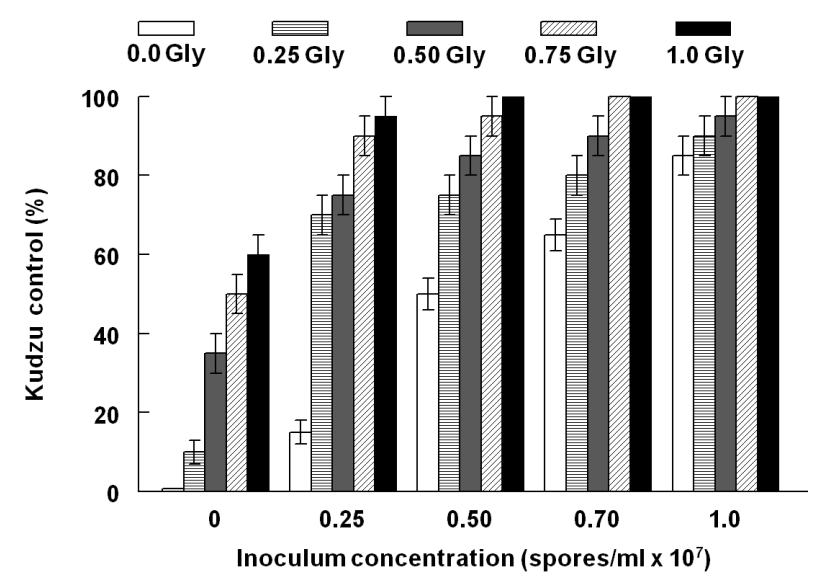

Figure 5. Effects of MV spores and glyphosate on kudzu control under field conditions, five days after treatment. Kudzu plants were 0.9 to $1.0 \mathrm{~m}$ tall at time of application. Glyphosate concentrations were 0.0 to $1.0 \mathrm{X}$ where $1.0 \mathrm{X}=1.12 \mathrm{~kg}$ ai. ha ${ }^{-1}$. Error bars represent FLSD $_{0.05}$.

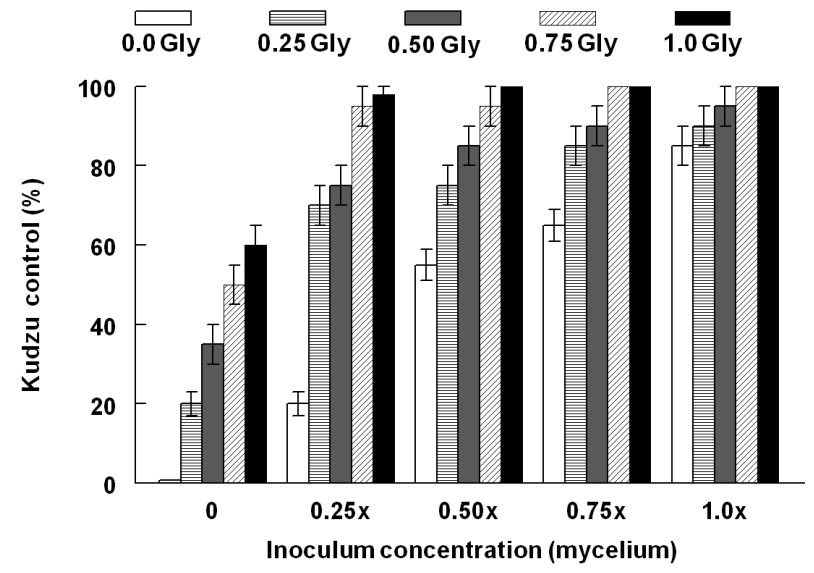

Figure 6. Effects of MV mycelia and glyphosate on kudzu control under field conditions, five days after treatment. Kudzu plants were 0.9 to $1.0 \mathrm{~m}$ tall at time of application. Glyphosate concentrations were 0.0 to $1.0 \mathrm{X}$ where $1.0 \mathrm{X}=1.12 \mathrm{~kg}$ ai. $\mathrm{ha}^{-1}$. Error bars represent FLSD $_{0.05}$.

Table 1. Interaction of Myrothecium verrucaria spores and glyphosate for controlling kudzu under field conditions .

\begin{tabular}{|c|c|c|c|c|c|c|}
\hline MV & GLY & & & & & \\
\hline Rate $^{b}$ & Rate $^{c}$ & 0.00 & 0.25 & 0.50 & 0.75 & 1.00 \\
\hline 0.00 & & 0 & 10 & 35 & 50 & 60 \\
\hline 0.25 & & 15 & $70(24)^{* *}$ & $75(45)^{* *}$ & $90(56)^{* *}$ & $98(\mathbf{6 6})^{* *}$ \\
\hline 0.50 & & 50 & $75(55)^{*}$ & $85(\mathbf{6 8})^{*}$ & $95(75)^{*}$ & $100(\mathbf{7 0})$ \\
\hline 0.75 & & 65 & $80(\mathbf{6 9})^{*}$ & $90(77)^{*}$ & $100(\mathbf{8 3})^{*}$ & $100(\mathbf{8 6})$ \\
\hline 1.00 & & 85 & $90(87)^{*}$ & $95(\mathbf{9 0})^{*}$ & $100(93)^{*}$ & $100(\mathbf{9 4})^{*}$ \\
\hline
\end{tabular}

${ }^{\mathrm{a}}$ Expected values (E; bold font) were determined using the Colby formula: $\mathrm{E}=\mathrm{X}+\mathrm{Y}-(\mathrm{XY} / 100)$. Additive interactions are denoted by an asterisk*; synergistic interactions are denoted by two asterisks ${ }^{* *} .{ }^{b} \mathrm{MV}$ rate, where $1 \mathrm{X}=1.0 \times 10^{7}$ spores $/ \mathrm{mL}$; ${ }^{\mathrm{c}}$ Rate of glyphosate, where $1 \mathrm{X}=1.12 \mathrm{~kg} / \mathrm{ha}$.

monitored over 120 h (Figure 7 and Figure 8). In field tests, 24 h after application, disease ratings were only 2.5 - 3.0 in kudzu plants inoculated by MV spores or mycelia alone (0.25X), whereas disease ratings were 8.5 8.8 when MV propagules and glyphosate were applied at $0.25 X$ rates each (Figure 8). Even 120 h after applica- 
Table 2. Interaction of Myrothecium verrucaria mycelium and glyphosate for controlling kudzu under field conditions ${ }^{\mathrm{a}}$.

\begin{tabular}{|c|c|c|c|c|c|c|}
\hline MV & GLY & & & & & \\
\hline Rate $^{\mathrm{b}}$ & Rate $^{c}$ & 0.00 & 0.25 & 0.45 & 0.75 & 1.00 \\
\hline 0.00 & & 0 & 20 & 45 & 50 & 60 \\
\hline 0.25 & & 20 & $70(\mathbf{3 6})^{* * *}$ & $75(\mathbf{4 8})^{* *}$ & $95(\mathbf{6 0})^{* *}$ & $98(\mathbf{6 8})^{* *}$ \\
\hline 0.50 & & 55 & $75(\mathbf{6 4})^{*}$ & $85(71)^{*}$ & $95(77)^{*}$ & $100(82)^{*}$ \\
\hline 0.75 & & 35 & $85(72)^{*}$ & $90(77)^{*}$ & $100(\mathbf{8 2})^{*}$ & $100(86)^{*}$ \\
\hline 1.00 & & 85 & $90(\mathbf{8 9})^{*}$ & $95(\mathbf{1 0 0})^{*}$ & $100(\mathbf{9 2})^{*}$ & $100(94)$ \\
\hline
\end{tabular}

${ }^{\mathrm{a}}$ Expected values (E; bold font) were determined using the Colby formula: $\mathrm{E}=\mathrm{X}+\mathrm{Y}-(\mathrm{XY} / 100)$. Additive interactions are denoted by an asterisk ${ }^{*}$; synergistic interactions are denoted by two asterisks* ${ }^{*}$. ${ }^{\mathrm{b}}$ The $1.0 \mathrm{X}$ MV mycelial concentration contained the equivalent of $50.0 \mathrm{~g}$ mycelium (dry weight basis) $/ \mathrm{L}$; ${ }^{\mathrm{C}}$ Rate of glyphosate, where $1 \mathrm{X}=1.12 \mathrm{~kg} / \mathrm{ha}$.

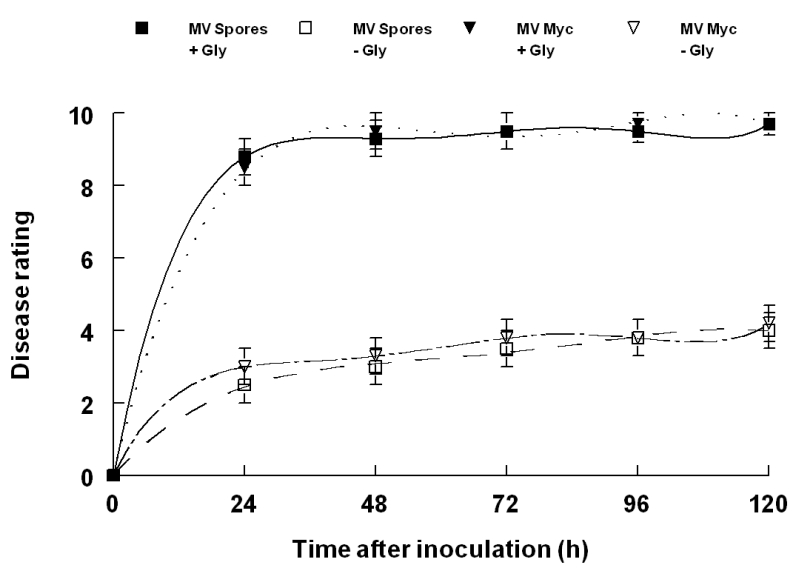

Figure 7. Disease progression caused by application of MV spores or mycelia alone, and combined with glyphosate at various concentrations under greenhouse conditions. Applications were: $0.25 \mathrm{X}$ each of MV spores or mycelia alone, and combined with glyphosate at $0.25 \mathrm{X}$ (see Materials and Methods for actual rates). Disease severity was based on a visual rating scale [86] (per plant basis) to estimate disease progression. A rating scale of 0 to 10 was used (as described in the Materials and Methods) and ratings were made at $24 \mathrm{~h}$ intervals over a $120 \mathrm{~h}$ time course. Symptomatology was considered severe at ratings of $8-10$. The relationship for these components is best described by the following equations: MV spores (open squares), $\mathrm{Y}=0.08-0.01 \mathrm{X}-0.02 \mathrm{X}^{2}+0.01 \mathrm{X}^{3}, \mathrm{R}^{2}=0.94$; $\mathrm{MV}$ mycelium (open, inverted triangle), $\mathrm{Y}=1.68+0.21 \mathrm{X}-$ $0.01 \mathrm{X}^{2}, \mathrm{R}^{2}=0.96$; MV spores plus glyphosate (solid squares), $\mathrm{Y}=-4.27+0.79 \mathrm{X}-0.02 \mathrm{X}^{2}, \mathrm{R}^{2}=0.98$; MV mycelium plus glyphosate (solid, inverted triangle), $\mathrm{Y}=-5.53+0.87 \mathrm{X}-0.03 \mathrm{X}^{2}, \mathrm{R}^{2}=0.98$. Error bars represent $\mathrm{FLSD}_{0.05}$.

tion, disease progression in MV propagule-treated plants increased to ratings of only $4.0-4.2$. In contrast, the combination of glyphosate with MV propagules caused increases in disease ratings of 9.6 - 9.7 after $120 \mathrm{~h}$. Similar results occurred under greenhouse conditions (Figure 7), and regression analyses revealed that MV spores or mycelia followed similar disease progression patterns, thus demonstrating high efficacy and little difference in the biological activity of these fungal propagules under greenhouse and field conditions (Figure 7 and Figure 8).

Since glyphosate and MV mixtures can result in synergistic interactions is important, in that glyphosate is not a restricted-use pesticide as are some other herbicides that are more efficacious for kudzu control. These results on bioherbicidal efficacy and synergistic interactions with glyphosate suggest the possibility of using combinations of glyphosate to improve bioherbicidal control potential, thereby reducing both herbicide and inoculum requirements of MV spores or mycelium for controlling kudzu. This commercial formulation of glyphosate was found to be compatible for mixing with MV for kudzu control. Other studies have shown that combinations of some herbicide formulation are detrimental to germination, growth and/or efficacy of MV [89].

The formulation ingredients vary among the commercially available glyphosate products and some of these components could be detrimental to fungal growth and/or pathogenesis when one of these products is combined with a pathogen used for weed control. Studies have shown that several formulations of glyphosate (e.g. Roundup-Ultra ${ }^{\circledR}$ ) combined with MV spores were inhibitory to fungal growth and disease development when sickelpod was used as the target weed [89]. However, in other studies, MV applied prior to glyphosate (Roundup-Ultra) application was found to provide control of natural infestations of redvine (Brunnichia ovata) and trumpet- 


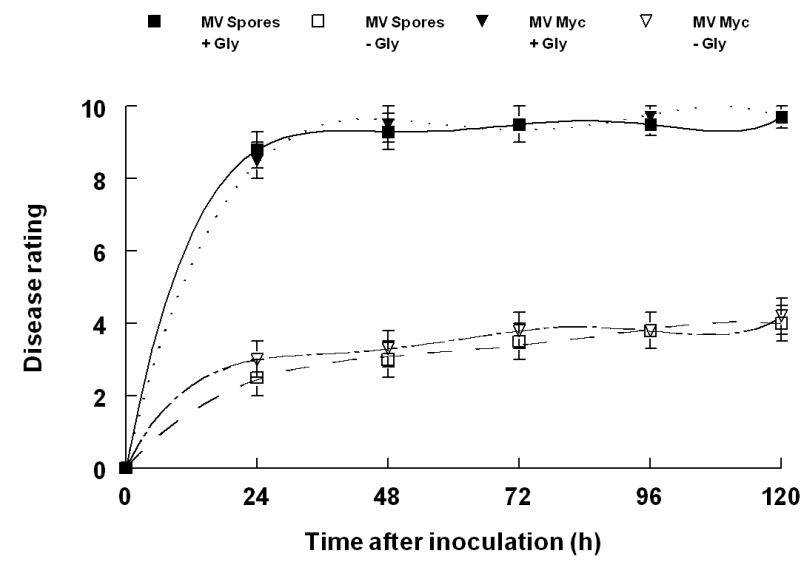

Figure 8. Disease progression caused by application of MV spores or mycelia alone, and combined with glyphosate at various concentrations under field conditions. Applications were: $0.25 \mathrm{X}$ each of MV spores or mycelia alone, and combined with glyphosate at $0.25 \mathrm{X}$ (see Materials and Methods for actual rates). Disease severity was based on a visual rating scale [86] (per plant basis) to estimate disease progression. A rating scale of 0 to 10 was used (as described in the Materials and Methods) and ratings were made at $24 \mathrm{~h}$ intervals over a $120 \mathrm{~h}$ time course. Symptomatology was considered severe at ratings of 8 - 10. The relationship for these components is best described by the following equations: MV spores (open squares), $\mathrm{Y}=0.01+0.17 \mathrm{X}-0.03 \mathrm{X}^{2}, \mathrm{R}^{2}=0.98$; MV mycelium (open, inverted triangles), $\mathrm{Y}=-2.81+0.30 \mathrm{X}-0.01 \mathrm{X}^{2}, \mathrm{R}^{2}=$ 0.98; MV spores plus glyphosate (solid squares), $\mathrm{Y}=-5.05+0.80 \mathrm{X}-0.03 \mathrm{X}^{2}, \mathrm{R}^{2}=0.98$; $\mathrm{MV}$ mycelium plus glyphosate (solid, inverted triangle), $\mathrm{Y}=0.01+0.17 \mathrm{X}-0.03 \mathrm{X}^{2}, \mathrm{R}^{2}=0.98$. Error bars represent $\mathrm{FLSD}_{0.05}$.

creeper (Campsis radicans) due to a synergistic interaction between the fungus and the herbicide [81]. In the present study we used another glyphosate product (Touchdown) combined (directly mixed) with MV spores or mycelium. Clearly the ingredients in the Touchdown formulation were not detrimental to MV under the environmental conditions and the concentrations used in these experiments (see Table 1 and Table 2). Since we were unable to obtain a formulation blank of Touchdown, we cannot be certain as to the possible effects of the increased concentration of "inert" ingredients as the herbicide rate was increased. As previously reported, MV requires a surfactant to facilitate pathogenesis [67]. Thus there could have been adjuvants or surfactants present in this glyphosate product that promoted efficacy of the herbicide/bioherbicide mixture. A strategy to avoid detrimental or antagonistic interactions caused by incompatible ingredients in herbicide formulations is split-timing applications of the herbicide and bioherbicide. This has been demonstrated in the case of another bioherbicidal fungus, Colletotrichum truncatum, which was tested at different inoculum concentrations alone, in combination with, prior to, or following glyphosate (Roundup Ultra) for control of hemp sesbania [80]. Hemp sesbania control and disease incidence was enhanced at low fungal and herbicidal rates when fungal spores were applied following glyphosate treatment. However, application of the fungus in combination with, or prior to sub-lethal glyphosate treatment resulted in reduced disease incidence and weed control.

The overall results here show that "high" MV spores or mycelia rates can provide adequate control of kudzu and that either propagule combined with glyphosate can result in synergized control of this weed. As pointed out previously, mycelia are the preferred propagules due to the absence of undesirable trichothecene levels [69] [71]. Further studies will be necessary to elaborate more precise parameters of these synergistic interactions with MV and glyphosate products for control of kudzu and other weeds.

\section{References}

[1] Harrington, T.B., Rader-Dixon, L.T. and Taylor, J.W. (2003) Kudzu (Pueraria montana) Community Responses to Herbicides, Burning, and High-Density Loblolly Pine. Weed Science, 51, 965-974. http://dx.doi.org/10.1614/02-142

[2] Hickman, J.E., Wu, S., Mickey, L.J. and Lerdau, M.T. (2010) Kudzu (Pueraria montana) Invasion Doubles Emissions of Nitric Oxide and Increases Ozone Pollution. Proceedings of the National Academy of Sciences, United States of America, 107, 10115-10119. http://dx.doi.org/10.1073/pnas.0912279107

[3] Gleason, H. and Cronquist, A. (1972) Manual of Vascular Plants of Northeastern United States and Adjacent Canada. New York Botanical Garden, New York.

[4] Forseth Jr., I.N., and Innis, A.F. (2004) Kudzu (Pueraria montana): History, Physiology, and Ecology Combine to 
Make a Major Ecosystem Threat. Critical Reviews in Plant Sciences, 23, 401-413. http://dx.doi.org/10.1080/07352680490505150

[5] Anonymous (2011) Kudzu. Conservation Commission of Missouri. Missouri Department of Conservation.

[6] Mitich, L.W. (2000) Intriguing World of Weeds. Kudzu Pueraria lobata (Willd.) Ohwi. Weed Technology, 14, 231235. http://dx.doi.org/10.1614/0890-037X(2000)014[0231:KPLWO]2.0.CO;2

[7] Wechsler, N.R. (1977) Growth and Physiological Characteristics of Kudzu, Pueraria lobata (Willd.) Ohwi, in Relation to Its Competitive Success. M.S. Thesis, University of Georgia, Athens.

[8] Tanner, R.D., Hussain, S.S., Hamilton, L.A. and Wolf, F.T. (1979) Kudzu (Pueraria lobata): Potential Agricultural and Industrial Resource. Economic Botany, 33, 400-412. http://dx.doi.org/10.1007/BF02858336

[9] Tsugawa, H., Tange, M., Kobayashi, R. and Nishikawa, K. (1986) Development of Root System in One-Year-Old Seedlings of Kudzu Vine Pueraria lobata. Science Reports of Faculty of Agriculture, Kobe University, Kobe, Vol. 17, $1-12$.

[10] Tsugawa, H., Sasek, T.W., Komatosu, N. and Nishikawa, K.I. (1990) Stems and Root Systems Just after the First Overwintering of Kudzu Pueruria lobata OHWI Stand Differing in Spacing. Journal of Japanese Grassland Society, 36, 99-106.

[11] van der Maesen, L.J.G. (1985) Revision of the Genus Pueraria DC. with Some Notes on Teyleria backer (Leguminosa). Wageningen Papers, Agricultural University Wageningen, Wageningen.

[12] Britton, K.O., Orr, D. and Sun, J. (2003) Invasive Plants of the Eastern United States. Kudzu. http://www.invasive.org/eastern/biocontrol/25Kudzu.html

[13] Pappert, R.A., Hamrick, J.L. and Donovan, L.A. (2000) Genetic Variation in Pueraria lobata (Fabaceae), an Introduced, Clonal, Invasive Plant of the Southeastern United States. American Journal of Botany, 87, 1240-1245. http://dx.doi.org/10.2307/2656716

[14] Jewett, D.K., Jiang, C.J., Britton, K.O., Sun, J.H. and Tang, J. (2003) Characterizing Specimens of Kudzu and Related Taxa with RAPDs. Castanea, 68, 254-260.

[15] Sun, J.H., Li, Z.C., Jewett, D.K., Britton, K.O., Ye, W.H. and Ge, X.J. (2005) Genetic Diversity of Pueraria lobata (Kudzu) and Closely Related Taxa as Revealed by Inter-Simple Sequence Repeat Analysis. Weed Research, 45, 255260. http://dx.doi.org/10.1111/j.1365-3180.2005.00462.x

[16] Keung, W.M. and Vallee, B.L. (1998) Kudzu Root: An Ancient Chinese Source of Modern Antidipsotrophic Agents. Phytochemistry, 47, 499-506. http://dx.doi.org/10.1016/S0031-9422(97)00723-1

[17] Miller, J. and Edwards, B. (1983) Kudzu: Where Did It Come from? And How Can We Stop It? Southern Journal of Applied Forestry, 7, 165-169.

[18] Everest, J.W., Miller, J.H., Ball, D.M. and Patterson, M.G. (1999) Kudzu in Alabama, History, Uses and Control. Alabama Cooperative Extension System ANR-65.

[19] Frye, M.J., Hough-Goldstein, J. and Sun, J.H. (2007) Biology and Preliminary Host Range Assessment of Two Potential Kudzu Biological Control Agents. Environmental Entomology, 36, 1430-1440. http://dx.doi.org/10.1603/0046-225X(2007)36[1430:BAPHRA]2.0.CO;2

[20] Miles, I.F. and Gross, E.E. (1939) A Compilation of Information on Kudzu. Mississippi Agricultural Station Bulletin, 326, 1-14.

[21] Edmisten, J.A. and Perkins, H.F. (1967) The Role and Status of Kudzu in the Southeast. Association of the Southeastern Biologists Bulletin, 14, 27.

[22] Blaustein, R.J. (2001) Kudzu’s Invasion into Southern United States Life and Culture. In: McNeeley, J.A., Ed., The Great Reshuffling: Human Dimensions of Invasive Specie, IUCN, The World Conservation Union, Gland and Cambridge, 55-62.

[23] Pieters, A.J. (1932) Kudzu: A Forage Crop for the Southeast. USDA. \#91, United States Department of Agriculture, Washington DC.

[24] Willard, C.J. (1926) An Interesting Root System. Journal of the American Society of Agronomy, 18, 725-727. http://dx.doi.org/10.2134/agronj1926.00021962001800080013x

[25] Bailey, R.Y. (1939) Kudzu for Erosion Control in the Southeast. USDA. \#1840, United States Department of Agriculture, Washington DC.

[26] McKee, R. and Stephens, J.L. (1943) Kudzu as a Farm Crop. USDA. \#1923, United States Department of Agriculture, Washington DC.

[27] Dalal, S.S. and Patnaik, N. (1963) Kudzu Cultivation for Soil Conservation. Indian Forestry, 89, 468-473.

[28] Hipps, C.B. (1994) Kudzu: A Vegetable Menace That Started out as a Good Idea. Horticulture, 72, 36-39. 
[29] Piper, C.V. (1920) Kudzu. USDA. \#1920, United States Department of Agriculture, Washington DC.

[30] Tabor, P. (1942) Observations of Kudzu, Pueraria thunbergiana Benth, Seedlings. Journal of the American Society of Agronomy, 34, 500-501. http://dx.doi.org/10.2134/agronj1942.00021962003400050012x

[31] Bailey, R.Y. (1944) Is It True? What They Say About Kudzu? Southern Seedsman, 7, 46-47.

[32] Nixon, W.M. (1948) Plant Kudzu from Seed. Crops and Soils, 1, 14-15.

[33] Everest, J.W., Miller, J.H., Ball, D.M. and Patterson, M.G. (1994) Kudzu in Alabama. Alabama Cooperative Extension Service Annual Circulation, 65, 8 p.

[34] Miller, J.H. (1997) Kudzu Eradication and Management. In: Hoots, D. and Baidwin, J., Eds., Kudzu: The Vine to Love or Hate, Suntop Press, Virginia Beach, 137-149.

[35] Tsugawa, H. and Kayama, R. (1976) Studies on Population Structure of Kudzu Vine (Pueraria lobata Ohwi). 3. Outline on Detachment of Rooted Nodes. Journal of Japanese Grassland Society, 22, 273-279.

[36] Tsugawa, H. and Kayama, R. (1978) Studies on Population Structure of Kudzu Vines (Pueraria lobata). 4. The Difference in the Distribution Pattern of Rooted Nodes and of Stumps Classified by the Developmental Stage of Their Root System. Grassland Science, 23, 307-311.

[37] Brender, E.V. (1960) Progress Report on Control of Honeysuckle and Kudzu. Southern Weed Conference Proceedings, 13, 187-192.

[38] Brender, E.V. (1961) Control of Honeysuckle and Kudzu. USDA. \#120, Forest Service, Southeastern Forestry Experiment Station, Washington DC.

[39] Davis, D.E. and Funderburke Jr., H.H. (1964) Eradication of Kudzu. Weeds, 12, 62-63. http://dx.doi.org/10.2307/4040646

[40] Southeast Exotic Pest Plant Council (2001) SE-EPPC Fact Sheet: Kudzu, Online. The Bugwood Network (Producer). The University of Georgia, College of Agricultural and Environmental Sciences/Warnell School of Forest Resources, Tifton. http://www.se-eppc.org/

[41] Virginia Department of Conservation and Recreation (2001) Invasive Alien Plant Species of Virginia. Fact Sheet: Kudzu (Pueraria lobata (Willd.) Ohwi), Online. http://www.dcr.state.va.us/dnh/fspulo.pdf

[42] Matlack, G.R. (2002) Exotic Plant Species in Mississippi, USA: Critical Issues in Management and Research. Natural Areas Journal, 22, 241-247.

[43] Swearingen, J., Reshetiloff, K., Slattery, B. and Zwicker, S. (2002) Plant Invaders of Mid-Atlantic Natural Areas. National Park Service and U.S. Fish and Wildlife Service. http://www.nps.gov/plants/alien/pubs/midatlantic/pumo.htm

[44] Virginia Department of Conservation and Recreation, Division of Natural Heritage (2003) Invasive Alien Plant Species of Virginia. In: Natural Heritage Program-Invasive Plants List. Virginia Department of Conservation and Recreation, Division of Natural Heritage, Virginia Native Plant Society (Producers), Richmond. http://www.dcr.virginia.gov/natural heritage/documents/invlist.pdf

[45] Dowdy, S. (2009) Kudzu Beetle-Bug Found in Georgia a Threat to Soybeans? Penton Publishing, New York.

[46] Dowdy, S. (2011) Kudzu Bug Spreading Rapidly across Southern States. Penton Publishing, New York.

[47] Christiano, R.S.C. and Scherm, H. (2007) Quantitative Aspects of the Spread of Asian Soybean Rust in the Southeastern United States, 2005 to 2006. Phytopathology, 97, 1428-1433. http://dx.doi.org/10.1094/PHYTO-97-11-1428

[48] Anonymous (2004) ASA Urges Science-Based Measures To Help Prevent U.S. Soybean Rust Invasion. Corn and Soybean Digest.

[49] Sharkey, T.D. and Loreto, F. (1993) Water-Stress, Temperature, and Light Effects on the Capacity for Isoprene Emission and Photosynthesis of Kudzu Leaves. Oecologia, 95, 328-333. http://dx.doi.org/10.1007/BF00320984

[50] EPA (2002) Nitrogen: Multiple and Regional Impacts. U.S. Environmental Protection Agency, Clean Air Market Programs, Washington DC.

[51] Hollis, J. (2006) The Mile-a-Minute Plant: Could the Ultimate Unwanted Heirloom Plant Develop into a Million-Dollar Crop? Mississippi Magazine, July 1.

[52] McGroarty, M.J. (2010) Kudzu, the Vine That Ate the South. How to Control Kudzu.

[53] Miller, J.H. and True, R.E. (1986) Herbicide Tests for Kudzu Eradication. Georgia Forestry Commission, 65, 1986.

[54] Miller, J. (1985) Testing Herbicides for Kudzu Eradication on a Piedmont Site. Southern Journal of Applied Forestry, 9, 128-132.

[55] Melancon, M. (2012) Goats and Sheep Are Great for Clearing out Unwanted Brush. Growing Georgia, April 19.

[56] Templeton, G.E. and Smith Jr., R.J. (1977) Managing Weeds with Pathogens. In: Horsfall, J.G. and Cowling, E.B., Eds., Plant Disease: An Advanced Treatise, Academic Press, New York, 167-176. 
[57] Charudattan, R. (2001) Biological Control of Weeds by Means of Plant Pathogens: Significance for Integrated Weed Management in Modern Agro-Ecology. Biological Control, 46, 229-260. http://dx.doi.org/10.1023/A:1011477531101

[58] Hoagland, R.E. (2001) Microbial Allelochemicals and Pathogens as Bioherbicidal Agents. Weed Technology, 15, 835857. http://dx.doi.org/10.1614/0890-037X(2001)015[0835:MAAPAB]2.0.CO;2

[59] Boyetchko, S.M., Rosskopf, E.N., Caesar, A.J. and Charudattan, R. (2002) Biological Weed Control with Pathogens: Search for Candidates to Applications. In: Khachatourians, G.G. and Arora, D.K., Eds., Applied Mycology and Biotechnology Agriculture and Food Production, Elsevier Sciences, Amsterdam, 239-274. http://dx.doi.org/10.1016/S1874-5334(02)80013-2

[60] Boyetchko, S.M., Peng, G. (2004) Challenges and Strategies for Development of Mycoherbicides. In: Arora, D.K., Ed., Fungal Biotechnology in Agricultural, Food, and Environmental Applications, Marcel Dekker, New York, 111-121.

[61] Charudattan, R. (2005) Ecological, Practical, and Political Inputs into Selection of Weed Targets: What Makes a Good Biological Control Target? Biological Control, 35, 183-196. http://dx.doi.org/10.1016/j.biocontrol.2005.07.009

[62] Hallett, S.G. (2005) Where Are the Bioherbicides? Weed Science, 53, 404-415. http://dx.doi.org/10.1614/WS-04-157R2

[63] Zidack, N.K. and Backman, P.A. (1996) Biological Control of Kudzu (Pueraria lobata) with the Plant Pathogen Pseudomonas syringae pv. phaseolicola. Weed Science, 44, 645-649.

[64] Walker, H.L. and Tilley, A.M. (1997) Evaluation of an Isolate of Myrothecium verrucaria from Sicklepod (Senna obtusifolia) as a Potential Mycoherbicide Agent. Biological Control, 10, 104-112. http://dx.doi.org/10.1006/bcon.1997.0559

[65] Anderson, K.I. and Hallett, S.G. (2004) Herbicidal Spectrum and Activity of Myrothecium verrucaria. Weed Science, 52, 623-627. http://dx.doi.org/10.1614/WS-03-101R1

[66] Hoagland, R.E., Boyette, C.D. and Abbas, H.K. (2007) Myrothecium verrucaria Isolates and Formulations as Bioherbicide Agents for Kudzu. Biocontrol Science and Technology, 17, 721-731. http://dx.doi.org/10.1080/09583150701527268

[67] Boyette, C.D., Abbas, H.K. and Walker, H.L. (2001) Control of Kudzu with a Fungal Pathogen Derived from Myrothecium verrucaria. US Patent No. 6274534.

[68] Boyette, C.D., Walker, H.L. and Abbas, H.K. (2002) Biological Control of Kudzu (Pueraria lobata) with an Isolate of Myrothecium verrucaria. Biocontrol Science and Technology, 12, 75-82. http://dx.doi.org/10.1080/09583150120093031

[69] Abbas, H.K., Tak, H., Boyette, C.D., Shier, W.T. and Jarvis, B.B. (2001) Macrocyclic Trichothecenes are Undetectable in Kudzu (Pueraria montana) Plants Treated with a High-Producing Isolate of Myrothecium verrucaria. Phytochemistry, 58, 269-276. http://dx.doi.org/10.1016/S0031-9422(01)00214-X

[70] Weaver, M.A., Boyette, C.D. and Hoagland, R.E. (2012) Bioherbicidal Activity from Washed Spores of Myrothecium verrucaria. World Journal of Microbiology and Biotechnology, 28, 1941-1946. http://dx.doi.org/10.1007/s11274-011-0996-8

[71] Boyette, C.D., Weaver, M.A., Hoagland, R.E. and Stetina, K.C. (2008) Submerged Culture of a Mycelial Formulation of a Bioherbicidal Strain of Myrothecium verrucaria with Mitigated Mycotoxin Production. World Journal of Microbiology and Biotechnology, 24, 2721-2726. http://dx.doi.org/10.1007/s11274-008-9759-6

[72] Hoagland, R.E. (1996) Chemical Interactions with Bioherbicides to Improve Efficacy. Weed Technology, 10, 651-674.

[73] Mitchell, J.K., Yerkes, C.N., Racine, S.R. and Lewis, E.H. (2008) The Interaction of Two Potential Fungal Bioherbicides and a Sub-Lethal Rate of Glyphosate for the Control of Shattercane. Biological Control, 46, 391-399. http://dx.doi.org/10.1016/j.biocontrol.2008.02.009

[74] Peng, G. and Wolf, T.M. (2011) Synergy between Synthetic and Microbial Herbicides for Weed Control. Pest Technology, 5, 18-27.

[75] Caulder, J.D. and Stowell, L.J. (1988) Synergistic Herbicidal Compositions Comprising Colletotrichum truncatum and Chemical Herbicides. US Patent No. 4775405.

[76] Christy, A.L., Herbst, K.A., Kostka, S.J., Mullen, J.P. and Carlson, P.S. (1993) Synergizing Weed Biocontrol Agents with Chemical Herbicides. In: Duke, S.O., Menn, J.J. and Plimmer, J.R., Eds., Pest Control with Enhanced Environmental Safety, American Chemical Society, Washington DC, 87-100.

[77] Sharon, A., Amsellem, Z. and Gressel, J. (1992) Glyphosate Suppression of an Elicited Defense Response. Increased Susceptibility of Cassia obtusifolia to a Mycoherbicide. Plant Physiology, 98, 654-659. http://dx.doi.org/10.1104/pp.98.2.654

[78] Peng, G. and Byer, K.N. (2005) Interactions of Pyricularia setariae with Herbicides for Control of Green Foxtail (Setaria viridis). Weed Technology, 19, 589-598. http://dx.doi.org/10.1614/WT-04-130R.1

[79] Hoagland, R.E., Boyette, C.D. and Vaughn, K.C. (2011) Interactions of Quinclorac with a Bioherbicidal Strain of My- 
rothecium verrucaria. Pest Technology, 5, 88-96.

[80] Boyette, C.D., Hoagland, R.E. and Weaver, M.A. (2008) Interaction of a Bioherbicide and Glyphosate for Controlling Hemp Sesbania in Glyphosate-Resistant Soybean. Weed Biology and Management, 8, 18-24. http://dx.doi.org/10.1111/j.1445-6664.2007.00269.x

[81] Boyette, C.D., Reddy, K.N. and Hoagland, R.E. (2006) Glyphosate and Bioherbicide Interaction for Controlling Kudzu (Pueraria lobata), Redvine (Brunnichia ovata) and Trumpetcreeper (Campsis radicans). Biocontrol Science and Technology, 16, 1067-1077. http://dx.doi.org/10.1080/09583150600828742

[82] Boyette, C.D., Hoagland, R.E., Weaver, M.A. and Reddy, K.N. (2008) Redvine (Brunnichia ovata) and Trumpetcreeper (Campsis radicans) Controlled under Field Conditions by a Synergistic Interaction of the Bioherbicide Myrothecium verrucaria and Glyphosate. Weed Biology and Management, 8, 39-45. http://dx.doi.org/10.1111/j.1445-6664.2007.00272.x

[83] Boyette, C.D., Hoagland, R.E. and Stetina, K.C. (2014) Biological Control of the Weed Hemp Sesbania (Sesbania exaltata) in Rice (Oryza sativa) by the Fungus Myrothecium verrucaria. Agronomy, 4, 74-89. http://dx.doi.org/10.3390/agronomy4010074

[84] Boyette, C.D. and Hoagland, R.E. (2004) Biocontrol of Kudzu (Pueraria lobata) is Synergized by Glyphosate Interaction. Proceedings of the Southern Weed Science Society, 57, 326.

[85] Steele, R.G.D., Torrey, J.H. and Dickeys, D.A. (1997) Principles and Procedures of Statistics-A Biometrical Approach. McGraw Hill, New York.

[86] Horsfall, J.G. and Barratt, R.W. (1945) An Improved Grading System for Measuring Plant Diseases. Phytopathology, 35, 655.

[87] Gomez, K.A. and Gomez, A.A. (1984) Statistical Procedures for Agricultural Research. 2nd Edition, Wiley, New York.

[88] Colby, S.R. (1967) Calculating Synergistic and Antagonistic Responses of Herbicide Combinations. Weeds, 15, $20-22$. http://dx.doi.org/10.2307/4041058

[89] Weaver, M.A., Jin, X., Hoagland, R.E. and Boyette, C.D. (2009) Improved Bioherbicidal Efficacy by Myrothecium verrucaria via Spray Adjuvants or Herbicide Mixtures. Biological Control, 50, 150-156. http://dx.doi.org/10.1016/j.biocontrol.2009.03.007 
Scientific Research Publishing (SCIRP) is one of the largest Open Access journal publishers. It is currently publishing more than 200 open access, online, peer-reviewed journals covering a wide range of academic disciplines. SCIRP serves the worldwide academic communities and contributes to the progress and application of science with its publication.

Other selected journals from SCIRP are listed as below. Submit your manuscript to us via either submit@scirp.org or Online Submission Portal.
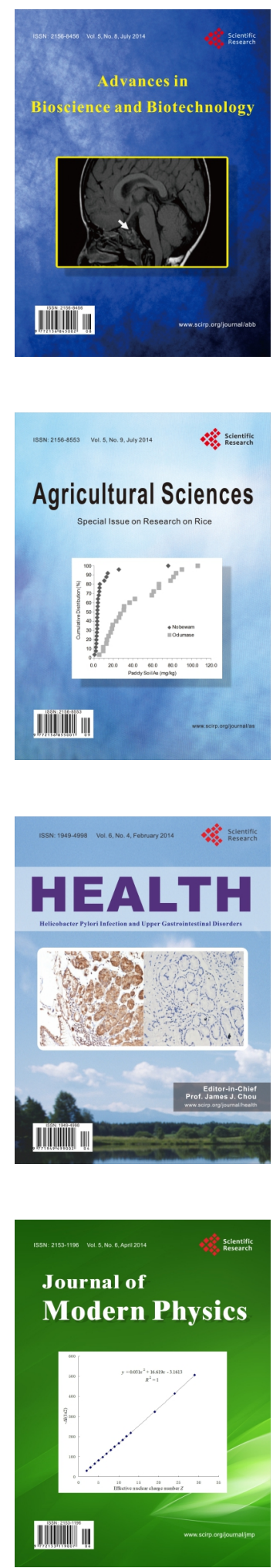
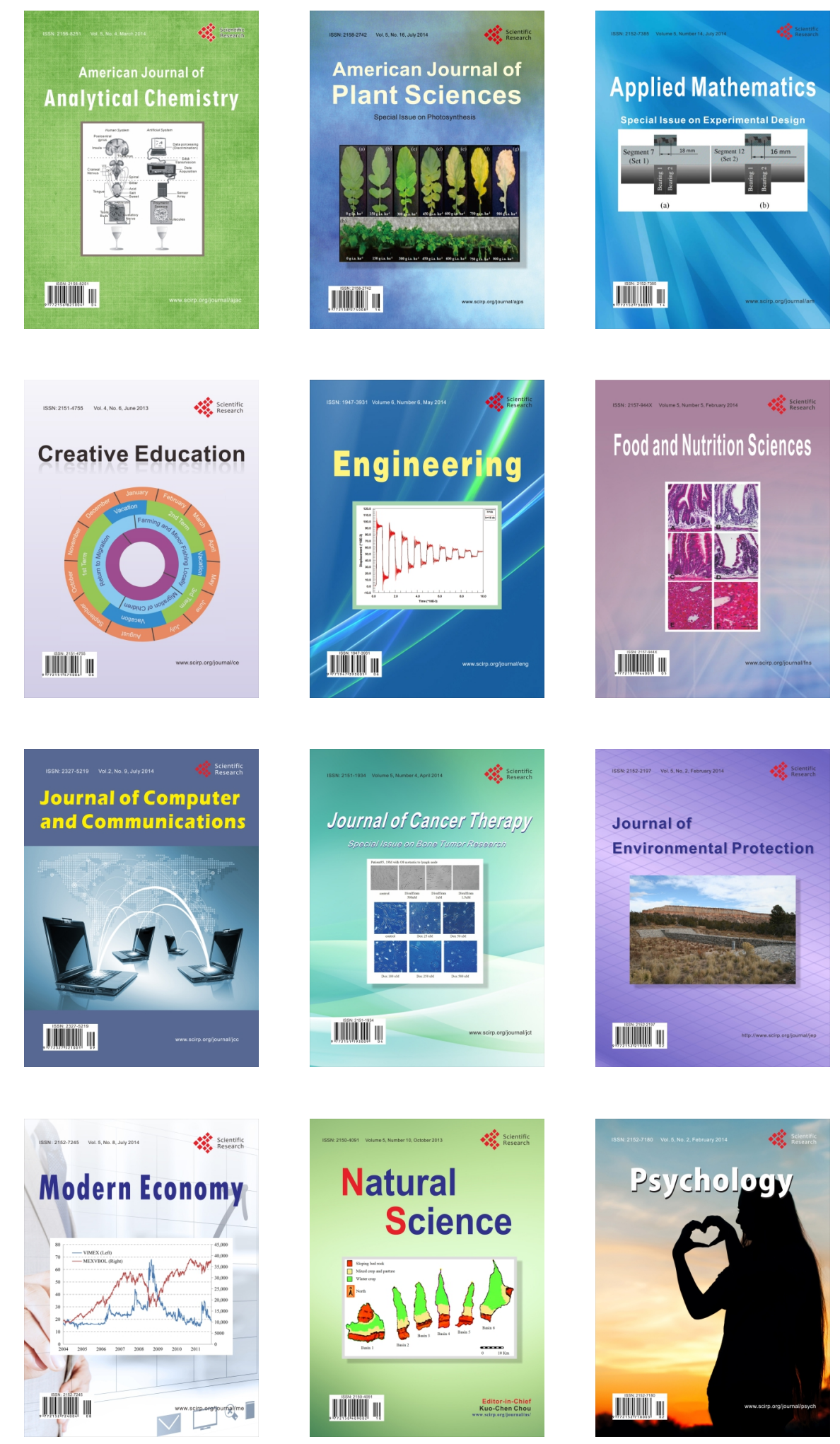